\title{
REVIEW PAPER ON SUSTAINABLE MANUFACTURING IN ASEAN COUNTRIES
}

\author{
Nohman Khan ${ }^{1 *}$, Ishamuddin Mustapha ${ }^{2}$, Muhammad Imran Qureshi ${ }^{3}$ \\ ${ }^{1}$ UniKL Business School Universiti Kuala Lumpur, Malaysia. \\ ${ }^{2}$ Malaysian institute of Industrial Technology (MITEC) Universiti Kuala Lumpur, \\ Malaysia. \\ ${ }^{3}$ Faculty of Technology Management and Technopreneurship, Universiti Teknikal Malaysia \\ Melaka, Malaysia
}

*Corresponding Author email: maliknohman@hotmail.com

Article History

Submission: May 05, 2020

Revised: June 08, 2020

Accepted: June 29, 2020

\begin{abstract}
The study is reviewing the work has been done on ASEAN countries sustainable manufacturing growth research. The ASEAN 10 member countries are keenly focus on the adaptation of sustainability in manufacturing processes and in their agenda of summits are raising the point to deliver. The past research will scientifically analyze to overview the comprehensive work has been done on manufacturing sustainability. The 1271 studies shown by the database web of science and another filter used of articles and review papers. The search is limited only on articles and review papers for literature review and after this database shown only 680 results. When the ASEAN countries filter used in database, for that purpose ASEAN 10 countries were selected to find the results. The database shown only 65 papers only. The studies are classified after the analyzing on the excel sheet according to the process. study is divided into three categories to understand the work has done on the research. Most of the previous sustainability manufacturing related review articles were based on environmental analysis and evaluation in manufacturing industries. There was a need to review the latest sustainability manufacturing studies in the manufacturing sector in order to show the recent status of sustainability manufacturing from the TBL perspective. The study has found some new concepts like industry 4.0 revolution in some literature and advance models of manufacturing for sustainability. The researcher must focus on the hybrid processes and IR 4.0 to establishing the sustainable manufacturing procedures in the ASEAN member countries.
\end{abstract}

Keywords: ASEAN, Sustainable Manufacturing

Abbreviations: NIL

\section{INTRODUCTION}

On 8 August 1967 the "Bangkok Declaration" gave birth to ASEAN, the Association of Southeast Asian Nations, an organization that would unite five countries in a joint effort to promote economic co-operation and the welfare of their peoples(asean.org). The Association of Southeast Asian Nations, or ASEAN, Founding Fathers of ASEAN, namely Indonesia, Malaysia, Philippines, Singapore and Thailand. Brunei Darussalam then joined on 7 January 1984, Viet Nam on 28 July 1995, Lao PDR and Myanmar on 23 July 1997, and Cambodia on 30 April 1999, making up what is today the ten Member States of ASEAN. The aim and purposes were about cooperation in the economic, social, cultural, technical, educational and other fields, and in the promotion of regional peace and stability through abiding respect for justice and the rule of law and adherence to the principles of the United Nations Charter. To collaborate more effectively for the greater utilization of their agriculture and industries, the expansion of their trade, including the study of the problems of international commodity trade, the improvement of their transportation and communications facilities and the raising of the living standards of their peoples. It 
stipulated that the Association would be open for participation by all States in the Southeast Asian region subscribing to its aims, principles and purposes. It proclaimed ASEAN as representing "the collective will of the nations of Southeast Asia to bind themselves together in friendship and cooperation and, through joint efforts and sacrifices, secure for their peoples and for posterity the blessings of peace, freedom and prosperity." (Park, Ungson, \& Francisco, 2016)

Chairman's statement of the (33rd ASEAN summit Singapore, 13 November 2018), talks about the sustainable green jobs in the member countries of ASEAN. ASEAN Declaration on Promoting Green Jobs for Equity and Inclusive Growth of ASEAN Community, as a sign of commitment to promote decent work that contributes to environmental and economic sustainability. To honor and implement commitments to multilateral and regional sustainable development and environmental agreements, to achieve the common goal of a clean and green ASEAN. () The intensify individual and collective efforts to improve the quality of air and water within ASEAN through regional or national initiatives to reduce industrial and transportation pollutions through sustainable manufacturing. ASEAN members have clear environmental agenda for implementation to preserve natural environment and produce sustainable manufacturing. ASEAN has concrete measures to promote the use of renewable and alternative energy sources such as solar, hydro, wind, tide, biomass, biofuels and geothermal energy, as well as, for interested parties, civilian nuclear power, while ensuring safety and safeguards that are of current international standards, and environmental sustainability throughout the full life cycle of production and use. ASEAN members are also agreed on intensify cooperation on the joint research, development and deployment of low emission technologies for the cleaner use of fossil fuels, recognizing that fossil fuels will continue to play a major role in sustainable manufacturing and energy mix.

The study is reviewing the work has been done on ASEAN countries sustainable manufacturing growth research. The past research will scientifically analyze to overview the comprehensive work has been done on manufacturing sustainability. The fast-growing world population and the growing demand for consumer goods put a concentrated compression on manufacturing industries. To meet these requirements, supplementary industries are established, and more manufactured products are brought to the markets. As a result, manufacturing activities consume a large amount of energy and natural resources (Linke, Corman, Dornfeld, \& Tönissen, 2013) and produce more emissions to air and land, while having significant implications for the society and economy. Manufacturing processes also have significant effects on the eco-system and human life.

The greatest common and cited definition of sustainability is derivative from the 'Brundtland Report' of the World Commission on Environment and Development (WCED, 1987, p. 1), in which sustainable growth means 'meeting the requirements at the current without compromising the ability of future generations to meet their own needs'. The reasons behind the growing interest in sustainability are inadequate resources(Daily \& Huang, 2001); over-population(Daily \& Huang, 2001); poverty condition industrialization(Barrera-Roldán \& Saldívar-Valdés, 2002); declining living 
values); poisoned natural resources global climate change; climb in the feeding of nonrenewable resources and concerned biodiversity and ecosystems(Jerneck et al., 2011). Such subjects are generating difficulties in accomplishing optimal development that are delaying companies' profitability. (Diesendorf, 1999) comprises the three philosophies of environmental protection, economic growth and societal equity within sustainability. These are sometimes mentioned to as the triple bottom line: social, economic and environmental or people, profit, and planet. Besides, supposed sustainability as the probable for dropping long-term hazards related with resource reduction, pollution and waste management. Management, supply chain, manufacture procedure, processes and engineering fields are careful in applying sustainability theory for enhanced output(Bakshi \& Fiksel, 2003).

Traditional research in manufacturing productions was mainly attentive on refining competence and plummeting cost ("The future of Manufacturing-Making things in a changing world," n.d.). However, at present, with growing responsiveness of severe sustainability-related matters, like global warming and climate change, the switch and decrease of environmental and social impacts have become an extra objective in manufacturing industries (Allen et al., 2002). Manufacturing industry has a key influence in the progress of an economy with manufacture of goods (Abdul-Rashid et al., 2017). Manufacturing segment has a significant role in sustainable development of the society. In a growing competitive atmosphere, sustainable manufacturing is flattering the style of survival for many organizations. Sustainable manufacturing contains the alteration from traditional procedures of manufacturing to the state-ofthe-art progressions that consider their outcome on atmosphere, culture and economy (Jawahir, Badurdeen, \& Rouch, 2013a). Sustainable manufacturing talks the problems connected to the strategy of procedures of manufacturing, the implementation of technologies along with complete business tactic (Petrini, Review, \& 2010, n.d.-a). The Construction on lean manufacturing and green manufacturing essentials, sustainable manufacturing delivers larger worth to all the shareholders. It emphasizes the practice of manufacturing practices which are biologically and socially answerable. Sustainable manufacturing range sounds for a complete understanding of the entire manufacturing supply chain as well as product lifecycle influence on economic, environmental and societal magnitudes (William \& Fazleena, 2014). Sustainable processes also protection the advanced supply plans with determined economic earnings (Upton, Teal, \& Felan, 2001). The goods and procedures as a conclusion of sustainable manufacturing have no dangerous effect on human well-being and society ((Beck et al., 2018). Sustainable manufacturing also maximizes the new opportunities for the firm in relations of new product development and new marketplace expansion (Brones, De Carvalho, \& De Senzi Zancul, 2014).

The ASEAN 10 member countries are keenly focus on the adaptation of sustainability in manufacturing processes and in their agenda of summits are raising the point to deliver. The sustainability manufacturing is needed to develop in procedures to enhance the quality of production and environment also. The sustainable manufacturing in the ASEAN countries published research will analyze to find out the quality of research and measure the areas of manufacturing discussed in past studies and suggest in which field of manufacturing research is need after the review 
analysis. The study also make overview the published research in ASEAN countries for finding the most work done on sustainable manufacturing in which country. The environmental protection is mainly discussing topic in most of summits of ASEAN, so the research quality and literature for the implementation of policy is also very important.

\section{METHODOLOGY}

Keywords searched were sustainable manufacturing, Triple-bottom-line, Sustainability assessment, Manufacturing industry. Generally, this paper implemented about of the organized literature review steps recommended by (Keathley-Herring et al., 2016). To kick-start the review, the scoping procedure was started throughout which a few essential papers on sustainability indicators and assessment were assessed. This process helped to regulate the obligatory features of the primary lessons and classify the possible search keywords (Keathley-Herring et al., 2016). The search focused on research articles published in English language in multiple journals.

Because of the limitlessness of the manufacturing area, a complete literature review was made, and web of science database use to find relevant scientific journals. Additional information sources included the United Nations Environment Programmed, ASEAN website and Chemistry, Foundation for Environmental Education and International Organization for Standardization. The sustainable manufacturing is used as key word for find the relevant studies in the web of science database. The filters are used to find the relevant studies and time frame is used for last 10 years from 2009 to 2018 on web of science. The 1271 studies shown by the database and another filter used of articles and review papers. The search is limited only on articles and review papers for literature review and after this database shown only 680 results. When the ASEAN countries filter used in database, for that purpose ASEAN 10 countries were selected to find the results. The database shown only 65 papers only. The possible data exported into excel sheet to continue the systematic review and 4 other papers were also remove from the excel sheet due to irrelevancy with the study. Figure 1 shows the detailed PRISMA Framework.

\section{REVIEW OF SUSTAINABLE MANUFACTURING}

The discussion on sustainability generally starts with (Held, n.d.) definition: "meeting the requirements of the current without compromising the capability of upcoming generations to encounter their own desires." The TBL idea of sustainability pursues to comprise all three dimensions of sustainability: environmental, economic and social. However, in research, more stress has been positioned on the environment as compared to the other two proportions of sustainability. In line with sustainability principles, sustainable manufacturing can be defined as "the invention of manufactured products done procedures that lessen harmful environmental impacts, conserve energy and natural resources, are safe for employees, societies, and clients and are economically sound". Sustainable manufacturing includes many practices, which deliver for improved environmental management by administrations. Sustainability issues are absorbed on how businesses can work out marketable duty by replying to essential, global environmental problems. Therefore, it is significant for 
the corporate segment to exceed the struggles between economic imperatives and environmental goals, and act as a substance in altering business events so that they are less harmful to the natural environment (Roxas \& Chadee, 2012)

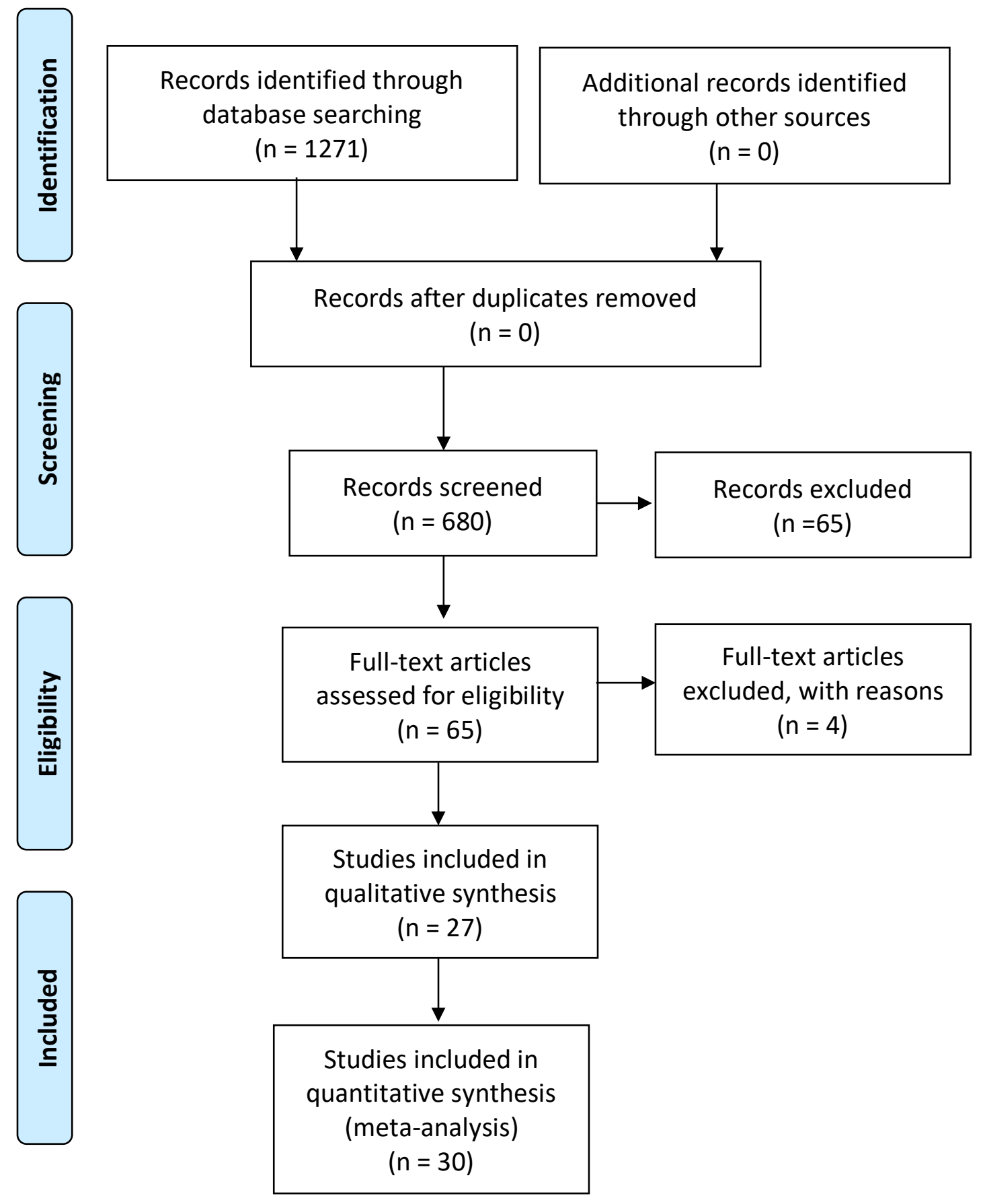

Figure 1: PRISMA Framework

Sustainable manufacturing continuum calls for a complete view of the entire manufacturing supply chain with product lifecycle influence on economic, environmental and societal magnitudes (Faulkner and Badurdeen, 2014). Manufacturing businesses are identifying the widespread benefits of sustainable manufacturing, acceptance its assistances in improving cost debauched (Donoghue et 
al., 1999), absolutely impressions monetary performance and marketplace presentation and delivers competitive lead (Yang \& Li, 2011). Overseeing sustainable manufacturing customs and incomes appeal developed cast and jurisdictive actions.

\section{QUALITY ASSESSMENT}

This paper includes original articles and review articles to find the batter outcomes and excellence overview of the earlier data. Next, abstracts and conclusions were separated to additional narrow down the archives. In adding, the references cited in the selected papers were also checked, as well as the articles citing our sampled papers. The records were check many times to avoid duplication and for improvement of desire results the irrelevant studies were also removed.

\section{ELIGIBILITY AND INCLUSION}

Criteria Among the identified pieces of literature, papers went through a stricter and more accurate selection according to the following criteria: To assure the high quality of selected papers, articles in English were chosen only if they were published in the web of science database. This paper reviews the sustainable manufacturing literature and overview the past studies done in ASEAN countries to improve the manufacturing processes. Most studies included quantitative results and some articles with qualitative analysis of high value were included as well as a few studies are based on review papers.

\section{STUDIES INCLUDED IN QUALITATIVE SYNTHESIS}

After selecting the 65 papers, the procedure involved two different consecutive steps. In the first step, the consistent metadata was imported into Microsoft Excel to experience a descriptive analysis of the literature on sustainable manufacturing in the field of sustainability such as the qualitative and quantitative work done in ASEAN countries. In the following step, an in-depth content analysis was assumed to classify and examine main investigation streams, reporting the state of the art of research across diverse themes and highlighting the conceivable challenges and opportunities for future research. Content analysis is a research approach to the analysis of documents and texts that seeks to describe and quantify the obvious content of communication in terms of prearranged groups, following a systematic method, permitting replicable and valid implications from texts.

\section{RESULT}

Descriptive, year base, journal base, country base, subject base and citation report.

\section{DESCRIPTIVE ANALYSIS}

Figure demonstrates the evolution several publications per year on the Sustainable manufacturing. The literature from ASEAN countries already published research is very much limited during the last 10 years but still study focus to find the best result for analyzing. In the study main idea is to find the sustainable manufacturing adaptation and procedures done by the researchers. Although the ASEAN countries organization is very much keen to create a batter environmentally friendly business and industries to clean the atmosphere. As time went by, the research in this field has grown steadily between the period of 215-2018, reaching a peak in 2018. It can be noted 
that most of the research articles have been published in the most recent years, the 33 summit of ASEAN in Singapore clearly optimize the policy on environmental issues and researchers are have open opportunity to produce research in member countries to identify the problem in manufacturing process and discuss new ideas about the manufacturing sustainability. This trend indicates that the study of Sustainable manufacturing perspective has increased significantly over the years and researchers are trending the sustainability of environment on priority basis. The agenda is to find the adaptation of sustainable manufacturing in the fields, the mega industries to SMEs in the member countries and how growing the industries towards the sustainable manufacturing. The study finds out the direction of the past study in the field of manufacturing and concepts which are widely and narrowly working in the manufacturing industries to formalize the environmental base activities.

\section{COUNTRY BASE}

The past studies analyses on country base work done in last 10 years. The highest studies produce by Malaysia on sustainable manufacturing with 38 numbers. The Malaysia work about sustainable environment is very acknowledgeable as compare to the other ASEAN countries. The second most work is done by the Singapore and Philippines with 10 studies from each country on sustainable manufacturing. The sustainable manufacturing field is focusing very less studies in the remaining part of the ASEAN members. The Brunei, Cambodia, Vietnam and Myanmar progress on sustainable manufacturing research studies are very low in numbers during the last decade. Figure 2 indicates the country base publications

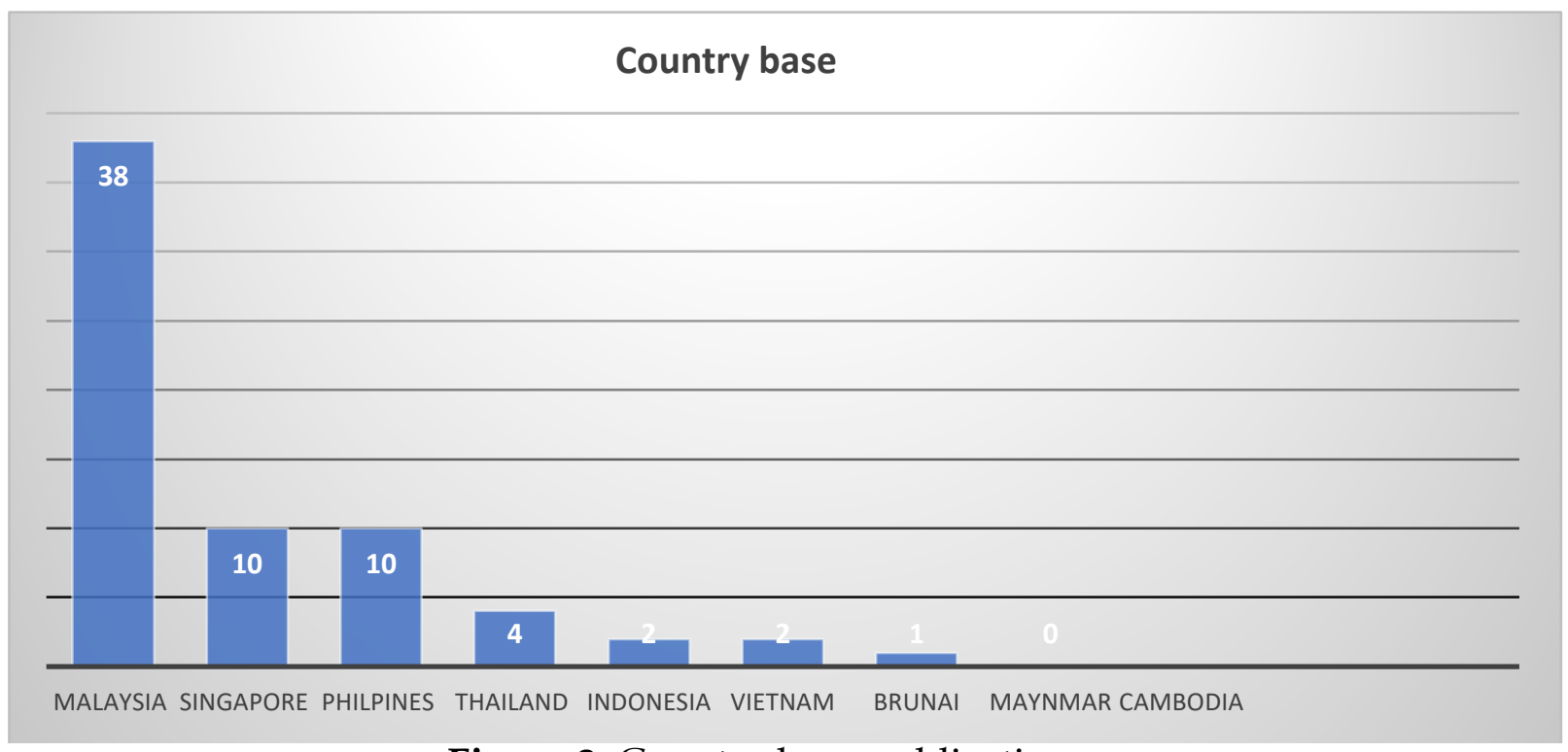

Figure 2: Country base publications

\section{SUBJECT BASE PERCENTAGE}

The ASEAN countries base published research have much work about Manufacturing engineering and almost 24 percent past studies focus the subject. So, the manufacturing is basically concern subject to the sustainable manufacturing and 
highly positive studies based on this. Manufacturing engineering has 15 past studies on the topic of sustainable manufacturing. The second largest studies come from green sustainable science technology with 21 percent publications. The green sustainable science technology subject is 14 researcher point out for the research and complete the study to identify the problems. The third subject area with highest studies is Environmental science scoring 12 past studies and 18 percent contribution in sustainable manufacturing in ASEAN countries. So, the most of work is one within the subjects and study identify all work to analyze. Figure 3 indicates the subject wise publications.

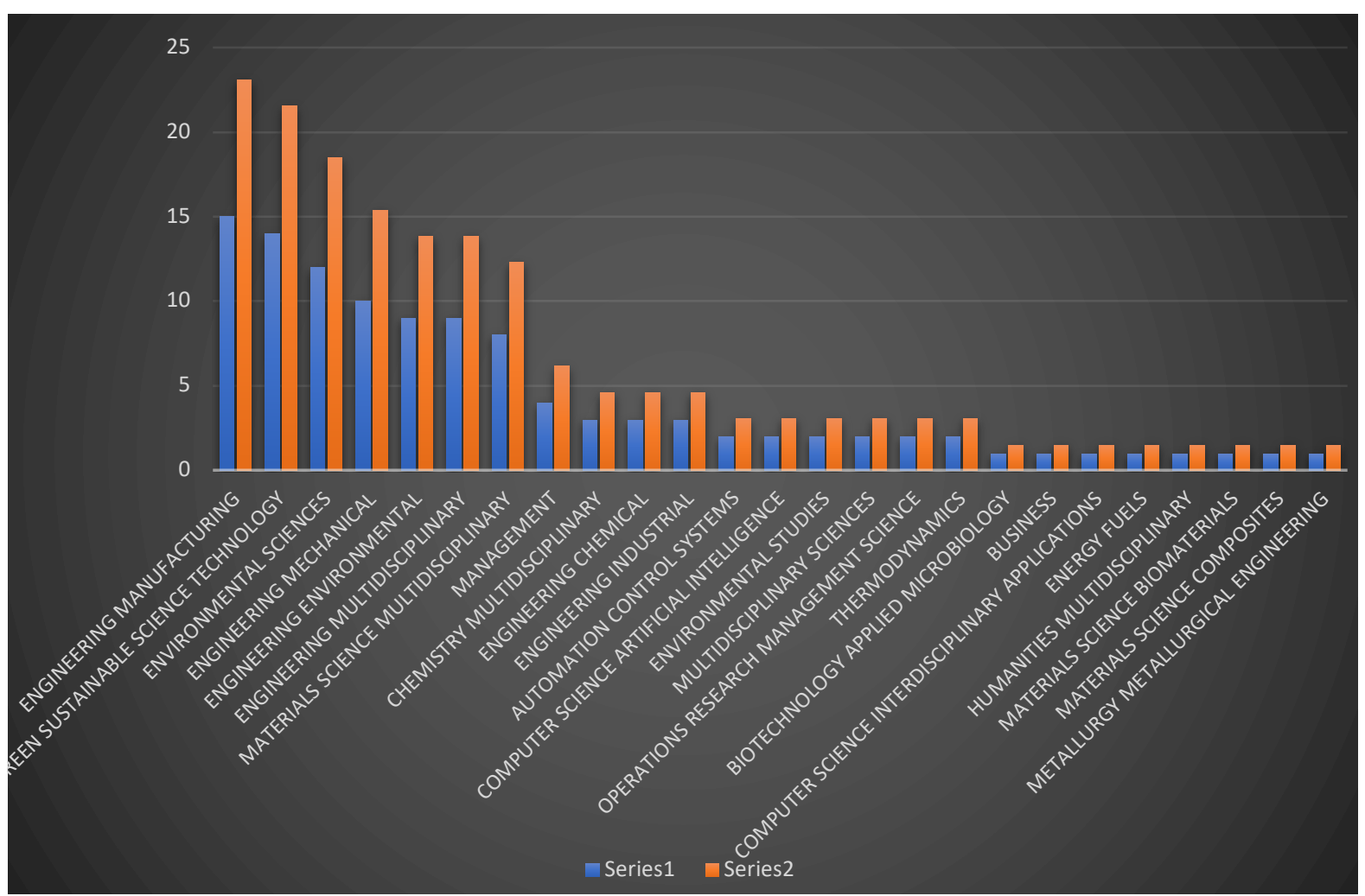

Figure 3: Subject wise publications.

\section{YEAR BASE}

The year base graph of sustainable manufacturing is shoeing results very differently. Most of the work on sustainable manufacturing is done in last 3 years. The highest number of publications are for 2015 to 2018. The graph shows that the year 2018, 17, and 16 are top ranked with 15 papers each year. The year 2015 also having score of 14 with articles. But the remaining years productivity by research in literature is very much limited. The year 2014 only having 4 studies on the topic of sustainable manufacturing. The sustainable manufacturing is relatively new concept for the industries and SMEs in ASEAN member countries. Figure 4 indicates the year wise publications. 


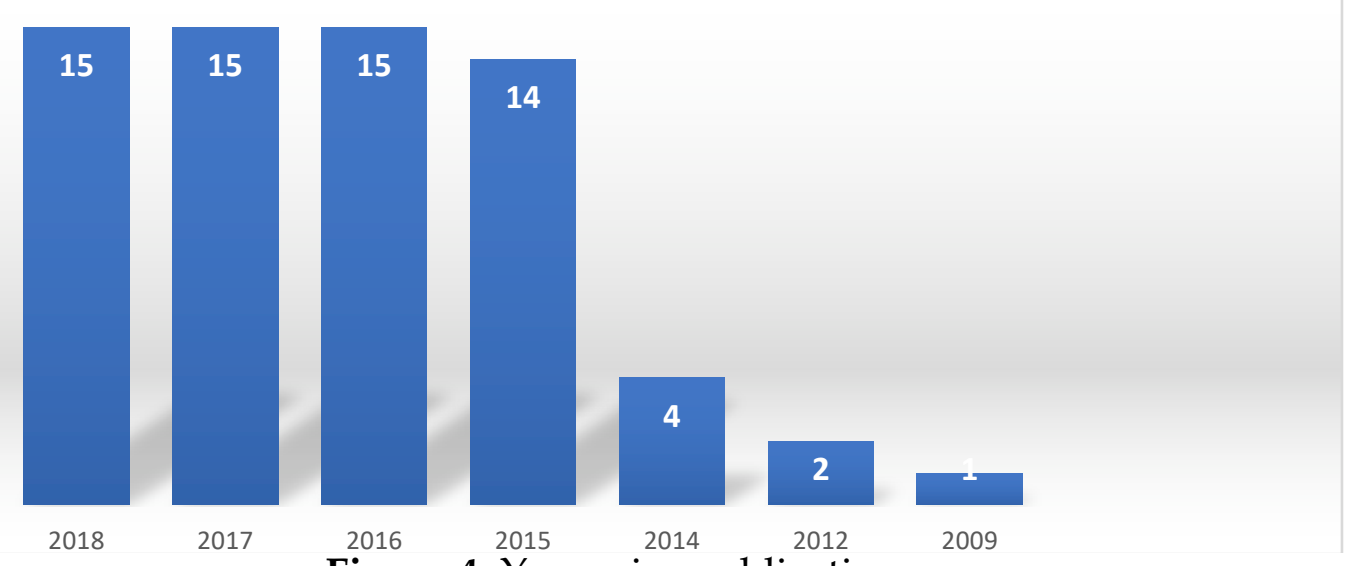

Figure 4: Year wise publications.

\section{CITATION REPORT}

The citation report of the studies in the 10 years from 2009 to 2018 is shown in the graph. The highest cited journal is journal of cleaner production with 62 times and article name is A weighted fuzzy approach for product sustainability assessment: a case study in automotive industry. The study is cited highest time and published in cleaner production journal. The study is cited more then 12 time in year 2018. After that the second most cited study is the need for global coordination in sustainable development and cited 49 time in ten years. The study is cited 7 time in year 2011 and published in journal of cleaner production. The 31-time citation of the article name Fuzzy-based sustainable manufacturing assessment model for SMEs is $3^{\text {rd }}$ most cited study in the last ten years. The study is published in the journal of Clean technologies and environmental policies and cited 11 time in year of 2018. The fourth study is A hybrid group leader algorithm for green material selection with energy consideration in product design, which is cited 27 times in ten years and published in journal of Cirp annals-manufacturing technology. There are some other citation studies and shown in the figure 5.

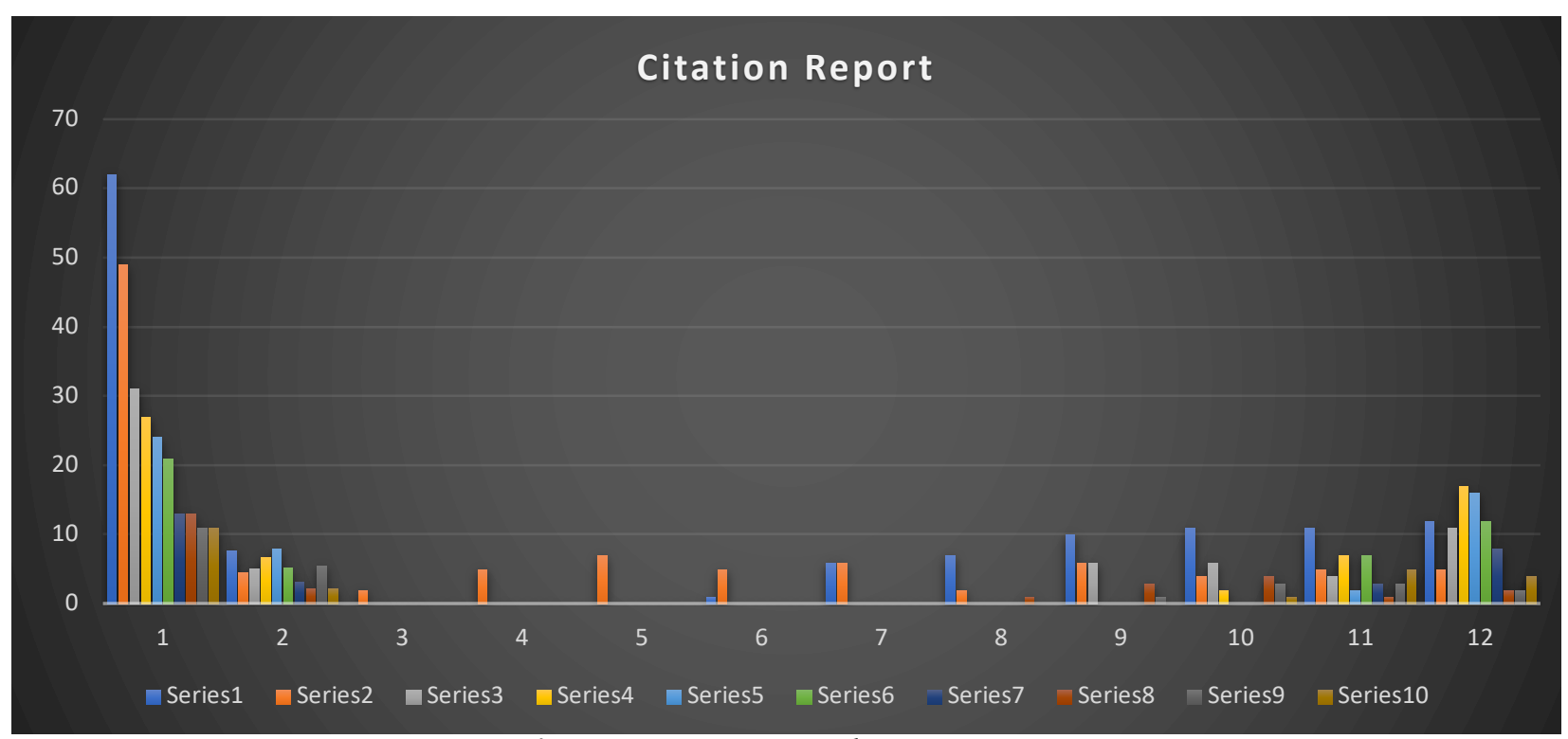

Figure 5: Most cited papers 


\section{JOURNAL BASE}

The journal base report on sustainable manufacturing in the ASEAN countries is shoeing in the graph list of all journals. The journal of cleaner production and journal of Technology is top of the list with 6 publications from each journal. The journal of materials is the second largest in the list with 3 studies and remaining list is also shown in the graph in which all the journals name is mention. The list is covering the complete publishing journal during the last ten years. Figure 6 shows the journals with most publications.

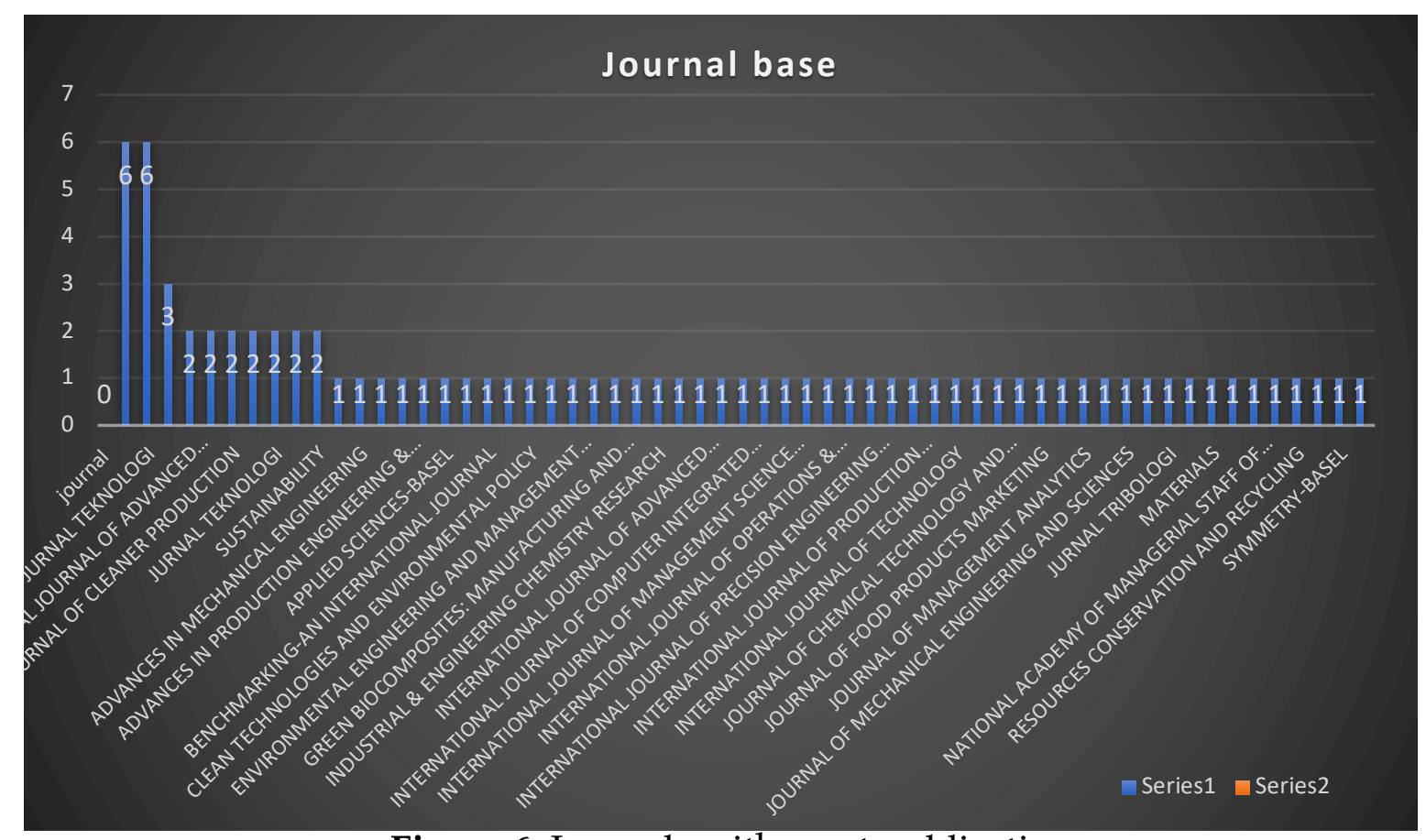

Figure 6: Journals with most publications

\section{CLASSIFICATION}

The studies are classified after the analyzing on the excel sheet according to the process. study is divided into three categories to understand the work has done on the research. Every single category is explained in detail to find the required information from the past research.

Method Base Classification.

The method base classification is further divided into three categories to understand the in-depth work is completed.

\section{QUANTITATIVE METHOD:}

Researchers who practice rational positivism or quantitative research employ investigational methods and quantitative measures to test hypothetical overviews (Hoepfl, 1997), and they also stress the dimension and analysis of causal relations between variables. To demonstrate the association of quantitative research for its use of explanation social problems, (Bogdan and Biklen, 1998). Quantitative research permits the researcher to explain him/herself with the problematic or idea to be 
deliberate, and possibly create theories to be confirmed. In this model: (1) the importance is on evidences and reasons of performance (Bogdan \& Biklen, 1998), (2) the information is in the procedure of statistics that can be calculated and summarized, (3) the mathematical procedure is the standard for examining the numeric data and (4) the final consequence is uttered in arithmetical terms. A quantitative researcher effort to piece and demarcate marvels into quantifiable or shared groups that can be practical to all the topics or broader and comparable circumstances (Winter, 2000). In his / her efforts, the researcher's approaches include the "use of homogenous events so that the variable standpoints and knowledges of people can be fit into an incomplete amount of prearranged reply groups to which amount are allocated" (Patton, 2002). a quantitative researcher desires to hypothesis a tool to be managed in consistent means conferring to programmed actions. But the enquiry is if the calculating tool proceedings what it is theoretical to measure. In the widest intelligence, planning a test (Crocker \& Algina, 1986) or the validity of a tool is on emphasis. The implication of this examination is to safeguard replicability or repeatability of the result.

The 30 studies are basing on quantitative method from 65 and use to analyze the quantitative methodology for research. The context of the quantitative studies is about green manufacturing in most of the studies. Green manufacturing contrasts from traditional manufacturing. Its emphases on environmental influence, environment policies of governments, national and international environmental regulations, stakeholder involvement and environmentalism, and modest weights Proper environmental regulations or standards can activate green innovations that really reduction cost, increase efficiency, or make businesses more competitive (Mishra, Sangwan, \& Sangwan, 2007). The advance manufacturing technology is also context is some of the quantitative base method studies. AMT was introduced when conservative manufacturing technology and computer-based controller technology joined (Swamidass \& Kotha, 1998) AMT mentions to a diversity of knowledges that apply the material and computer technologies in the manufacturing actions moreover straight or circuitously (Zhou, Keong Leong, Jonsson, \& Sum, 2009). AMT is a multidimensional idea and mainstream of prior studies incline to agree on classifying AMT in three sub-dimensions of plan and manufacturing-related technologies, process-related shop floor technologies, and information and control (administrative) related technologies (Adler, 2012).

The quantitative method also discusses in the past studies about the recycling technique of manufacturing to overcome the waste from manufacturing units to sustain the environment. Some of the studies raise the sustainable manufacturing performance. Sustainable manufacturing practices are one of the important environmental initiatives (Rashid, Evans, \& Longhurst, 2008).It is usually apparent that applying sustainable manufacturing will progress environmental performance. (Rusinko, 2007) observed sustainable manufacturing performs and their association with competitive manufacturing consequences and the outcomes displayed that pollution prevention practices are associated with a reduction in manufacturing cost and improving in sustainable manufacturing performance. The past studies also contributed about the waste minimization in the manufacturing industries. One way to endorse waste minimization is by using informational involvement policies. 
Informational policies purpose to modification people's information, perceptions, inspirations or standards and thereby endorse sustainable waste behavior (Messick \& Brewer, 1983). For example, informational strategies may provide people with knowledge on how and where to recycle, pointing to upsurge reprocessing performance. The energy saving is also discussing in the few studies to promote sustainable manufacturing with the aim of environmental greening.

The sustainable manufacturing, green manufacturing and recycling is the most frequent topic discuss in the quantitative method in contextual point of view. The sustainable Manufacturing industry has a key input in the development of an economy with production of goods (Abdul-Rashid et al., 2017). Manufacturing sector has an important role in sustainable growth of the humanity. In an growing competitive environment, sustainable manufacturing is flattering the elegance of existence for numerous companies (Moldavska \& Welo, 2017). Sustainable manufacturing contains the transformation from traditional procedures of manufacturing to the state-of-the-art processes that reflect their consequence on environment, society and economy (Jawahir, Badurdeen, \& Rouch, 2013b). Sustainable manufacturing addresses the problems connected to the design of procedures of manufacturing, the implementation of technologies sideways with complete business tactic(Petrini, Review, \& 2010). A manufacturing system reflects the fundamentals of sustainability along with strategy of products. Capability of a firm to invent at the wanted pace to fulfill with buyer requirements define the sustainable method (Jawahir et al., 2013). Valuation of entire product and service life cycle demonstration the strength of the sustainable image of a firm. The feature of remanufacturing, recyclability and termination of lifecycle management of products is another vital area in terms of sustainable organization (Herrmann \& Roux, 2016). Sustainable processes help the organizations to strive globally as well as locally. The combination of the procedures and environment concealments the important part of sustainable operations(Thomé, Scavarda, \& Scavarda, 2016). Recycling processes are very important in modern revolutionary age of technology. One of the most critical issues regarding the viability of product recycling is the availability of markets for the recovered materials. (Rahimifard, Coates, Staikos, Edwards, \& Abu-Bakar, 2009). Historically, products collected mostly of metallics have been mostly improved, due to the availability of established reprocessing technologies and global second-use demand.

The quantitative method discusses most of the areas in sustainable manufacturing in the ASEAN member countries. In the quantitative method emphasizes on the sustainable manufacturing, greening the environment and recycling of the manufacturing processes. Still there is need to produce some quality work in the area to improve the literature on sustainable manufacturing. The studies are not focus on the adaptation of technology that is available in the developed countries. The procedures which are novel in the field of sustainable manufacturing. The recycling and remanufacturing processes are not discussed in detail, which are most popular ideas in the manufacturing field. Researchers need to enhance the quality research on sustainable manufacturing in the ASEAN countries. Figure 7 shows the classification of literature. 


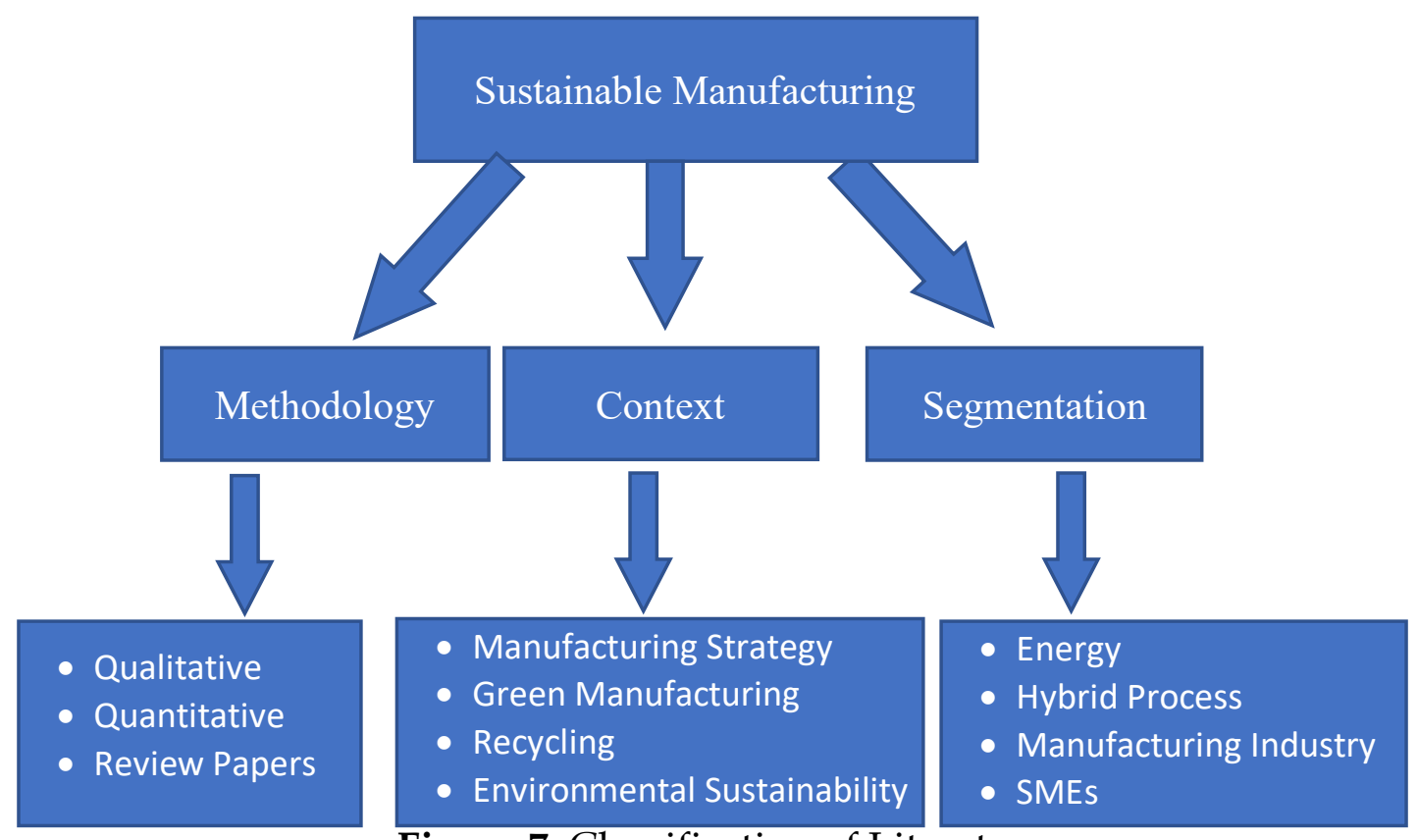

Figure 7: Classification of Literature

\section{QUALITATIVE METHOD}

Qualitative research usages a realistic tactic that pursues to realize singularities in context-specific settings, such as "real world setting [where] the researcher does not effort to manipulate the phenomenon of concentration" (Patton, 2001). Qualitative research, generally defined, means "any sympathetic of research that produces results not arrived at by means of statistical procedures or other means of quantification" (Ozanne, Strauss, \& Corbin, 1992) and instead, the kind of research that produces conclusions arrived from real-world settings where the "singularity of concentration explain logically" (Patton, 2001). Unlike quantitative researchers who pursue fundamental purpose, prediction, and generalization of findings, qualitative researchers pursue instead lighting, sympathetic, and extrapolation to comparable circumstances (Hoepfl, 1997). Qualitative analysis consequences in a dissimilar type of knowledge than does quantitative review because one party claims from the fundamental logical nature of each model, appreciating comprehensive interviewing and the other focuses on the apparent compatibility of the research methods, "enjoying the rewards of both numbers and words" (Glesne, 2006)). This means such methods like interviews and observations are leading in the environmentalist (interpretive) model and additional in the positive model, where the use of survey serves in opposite order.

The qualitative method has 27 studies in the published background and the studies focuses on different fields. The supply chain management is very first focus by the past studies and researcher identify supply chain channels loops for sustainable manufacturing. SCM stresses the unified addition of value-creating actions crossways administrative limitations to transport products and services to the market (Hsu, Kannan, Tan, \& Leong, 2008). Execution of SCM permits companies to remove waste, create synergy, and compete more efficiently in a penetratingly competitive global market. SCM practices exist in numerous systems dependent on factors such as 
industry, product type, and level of integration. The principle objective of SCM is to change intra- and inter-organizational, boundary spanning relationships that allow supply chain memberships to manage and integrate their activities and leverage their separate competences. Composite materials are used in an extensive range of applications such as automotive, aerospace and renewable energy industries. But they have not been correctly recycled, due to their characteristic nature of heterogeneity, in specific for the thermoset-based polymer compounds. The current and future waste management and environmental legislations need all engineering materials to be correctly recovered and recycled, from end-of-life (EOL) products such as automobiles, wind turbines and aircrafts. Recycling will eventually lead to resource and energy saving. Various technologies, mostly focusing on reinforcement fibers and yet to be commercialized, have been developed: mechanical recycling, thermal recycling, and chemical recycling. However, lack of passable markets, high recycling cost, and lower quality of the Recycles are the key commercialization barriers. The zero-waste manufacturing is also very much focusing in the past studies. According to. The word "Waste" normally stresses something around us which should be recycle, re-used, reduced or even eliminated, if possible. A huge quantity of waste, such as: electronics/electrical items, manufacturing scrap, discarded constructional materials, polymers from daily requirements, etc., is being produced day-by-day, whereas its handling is lagging. The term zero waste $(\mathrm{ZW})$ is uninterruptedly inspiring both producers and consumers to implement sustainable tactics in order to decrease their expenses as well as to help in creation a healthier world. In the past, researchers have emphasized several methods to challenge physical waste, however the chemicals which are usually produced from this waste is more dangerous and limitedly reported. Zero Waste Manufacturing (ZWM) is supposed as a roadmap for upcoming of manufacturing by which the red-hot issue of "Waste" can be tackled. Very important focus of the qualitative method studies in past literature is industry 4.0 revolution. The phenomenon of Industry 4.0 was first declared in 2011 in Germany as a suggestion for the expansion of a new idea of German economic policy based on high-tech approaches (Mosconi, 2015). The concept has launched the fourth technological revolution, which is grounded on the concepts and technologies that include cyber-physical systems, the Internet of things (IoT), and the Internet of services, based on continuous communication via Internet that permits a continuous communication and discussion of information not only between humans (C2C) and human and machine (C2M) but also between the machines themselves (Durden, Cooper, \& Terrill, 2007). This communicational contact effects the formation of knowledge management 4.0 (Roblek, Meško, \& Krapež, 2016). Manufacturing industry is a discussed in qualitative method to Recent advances in manufacturing industry has surfaced way for a systematical placement of Cyber-Physical Systems (CPS), within which data from all connected standpoints is thoroughly observed and synchronized between the physical factory floor and the cyber computational space. Moreover, by applying advanced information analytics, networked machines will be able to perform more efficiently, collaboratively and robustly. Such trend is transforming manufacturing industry to the next generation, namely Industry 4.0. At this early development phase, there is an urgent need for a clear definition (Lee, 2015). 
The qualitative method studies comparatively make deeper research about the sustainable manufacturing. Most of the fields and advancements of the area are identify, where the researcher has published the work. Still there is need to broader the research paradigm to improve the ability. The concept of lean management and environmental sustainability is not be centralized in the past studies with qualitative methods. For sustainable manufacturing advance manufacturing technologies are essential to improve the quality and growth with the environmental sustainability. So future researcher must focus with the concept of advancement and removal of waste.

\section{REVIEW PAPERS}

A review of preceding, applicable literature is a vital feature of any academic development. An operative review creates a firm groundwork for advancing knowledge. It enables theory development, conclusions areas where an excess of research happens, and exposes areas where research is required (Zweig \& Webster, 2002). The review literature also discusses in depth the concepts of sustainable manufacturing. The past literature has much of work in review method on lean manufacturing. Lean concepts are mostly grown from Japanese industries specially from Toyota. (Aravind, 2013)Lean Manufacturing is a waste decrease method as recommended by many authors, but in preparation lean manufacturing maximize the value of the product through minimization of waste. Lean principles describe the worth of the product/ service as perceived by the customer and then creation the flow in-line with the customer pull and determined for excellence through continuous development to remove waste by categorization out Value Addition activity (VA) and Non- Value-Added activity (NVA). The review method literature also discussed the green manufacturing that is concern of the modern world today. Following the green manufacturing (GM) of products is very valuable in the mitigation of environment problems. In order to obtain such reimbursements, GM is involved in every characteristic of manufacturing process. Throughout the machining process, manufacturing is one of the key roots of environmental pollution, with the optimum collection of manufacturing for GM being a significant track to decrease the environmental pollution. The objective factors of decision-making difficulties in the traditional collection of manufacturing are usually two: quality and cost; but from the viewpoint of GM, environmental impact (E) should also be considered (Aravind, 2013). Another important concept in past study is mentioned that is triple bottom line (TBL) concept. The TBL is an accounting context that incorporates three magnitudes of performance: social, environmental and financial. This changes from traditional reporting frameworks as it includes ecological (or environmental) and social measures that can be difficult to assign suitable means of amount. The TBL dimensions are also commonly called the three Ps: people, planet and profits. We will mention to these as the 3Ps.

The review literature the researchers done batter work and cover up the new ideas of sustainable manufacturing. The literature studies are not widely discussing the manufacturing sustainability in the past reviews. For the future researchers need to emphasize on different directions of sustainable manufacturing. They need to highlight the developed world concepts of manufacturing technologies to enhance the 
ability of manufacturing industry. The review studies are lack of the theories which are adopted by the manufacturing industries in the ASEAN countries and some basic techniques which essential part of the modern manufacturing are. The researcher must allocate the direction of future research in manufacturing for sustainable environment.

\section{SEGMENTATION}

The segmentation of past literature is based on different fields and industries in sustainable manufacturing. The most widely discuss segment in past studies is about manufacturing industries. (Bogue, 2014) Manufacturing industries have observed many challenges in the previous four decades, connecting radical changes in advanced capability, research and development business policy, export orientation, elasticity, customer satisfaction and other associated problems. These challenges are convincing the manufacturing organizations to implement an innovative procedure to change new products and to adventure sustainable manufacturing gears and techniques proficiently. Manufacturing performs a vital process in the business of the internationally industrialized republics, but its influence on the environment has become a matter of apprehension, which needs industries to implement sustainable manufacturing. Manufacturing industries and SMEs are more important for any economy. As cited in (Broman \& Robèrt, 2017)indicated that if humans continuous to disrespect the reimbursements to ecosystems and increase the risk to the biosphere, then humanoid civilization will be extremely pretentious(Trianni, Cagno, Marchesani, \& Spallina, 2017)highlighted the essential to recover the sustainability of manufacturing segment because current production models present a non-sustainable development trend; hence, technology, management, organization, and performance of the production system need change and (Blok \& Lemmens, 2015). (Mazzarol, Volery, Doss, \& Thein, 1999)emphasized that small and medium-sized enterprises (SMEs) play a key role in national economic growth. (Hillary, 2004) projected that SMEs can be accountable for up to $70 \%$ of all pollution worldwide. Determining the suitable management system to guarantee sustainable development is a significant subject for SMEs, not only because of pressure from shareholders but also from the enterprise development viewpoint of the supply chain management (Burke, 2007). SMEs need a suitable management technique and an applied agenda for the documentation and application of sustainable expansion strategies. The energy and power sector in sustainable manufacturing is also observed in past studies. The energy and power industries are vital part of sustainable manufacturing in present times. The sustainability needs effective utilization of energy to manufacturing processes. The saving of power and energy resources are creating value for expansion of industries for manufacturing demand fulfillment. the past literature also discussing in some studies about the hybrid processes of manufacturing. Hybrid manufacturing processes are grounded on the immediate and measured communication of process mechanisms and/or energy foundations/gears having a important consequence on the process performance. These procedures have a huge effect on the processing/manufacturing features resultant in higher machinability, decreases of process forces and instrument costume, etc. Due to the mutual action of processes, it also has an significant and most of the time positive outcome on the superficial 
integrity of machined parts (Lauwers et al., 2014). Past studies also point out the chemical and pharmaceutical industries in sustainable manufacturing perspective. Despite the sensitive perseverance of decrease carbon emissions around the world, the healthcare segment in overall, and the pharmaceutical area have established very slight consideration from the sustainability community in relationships of their influence to the worldwide carbon footprint. In this paper, we conduct an analysis of the overall contributions and the historical emissions leanings of the pharmaceutical segment, as well as an industry-specific relative study of the key pharmaceutical companies in the world ((Belkhir et al., 2014).The automotive industry is part of manufacturing industries and observed in past studies frequently. Sustainable development is occasionally understood as an eventual value system to give alignment for decision making and achievement in dissimilar circumstances. It is a context for businesses and their management to convert their accountability for environmental, economic and social performance into business practices within the legality of our society. As one, the automotive industry establishes a product system that directly and indirectly narrates to economic prosperity formation as well as influences on the natural and human environment along all phases of the product's life cycle. Automakers therefore performance a significant character for the environmental and social expansion of our world in the situation of sustainability. They must respond to progressively strict governmental regulation and environmental and social expectations by applying management strategies (Trace, 2007). The past literature also identifies the contribution towards the remanufacturing of waste and used materials, the segmentation of literature talks about remanufacturing briefly. Emerging sustainable methods to manufacture is a serious international concern. Important actions towards this contain working strategy for environment (Eco design), for improving remanufacturing capability and effectiveness. Remanufacturing is a procedure of bringing used products to a "likenew" useful state with guarantee to match. Its implication is that it can be both gainful and less damaging to the environment in judgement to conventional manufacturing. Remanufacturing has a low shape in world economies and is poorly understood because of its relative novelty in research terms. However, environmental and competitive compressions are changing the global and business environment, and this is fueling attention in the exercise.

After this the past study discusses some other vital perspectives about segmentation, like aluminum and light metal industries for sustainable manufacturing environment. The past literature also reviewed towards the palm industry in Malaysia and aerospace sectors of industry. The sustainable manufacturing in ASEAN countries past studies researchers done quality work on some of areas but still large work is needed to do. The researcher has more large and wide range of industries and Small Medium Enterprise SMEs to explore the sustainable manufacturing field. This will also create opportunity for organizations to pursue the solution of sustainability according to the nature of problem.

\section{CONTEXT}


The context of the published research is mostly covering the manufacturing strategies A general method for planning manufacturing strategies on these magnitudes is defined. For each manufacturing group, the relations between the competitive competences (which describe the manufacturing task), the business context (the business unit strategy), manufacturing activities (manufacturing strategy choices), and manufacturing performance measures are explored and compared (Miller \& Roth, 2008). According to (Hillary, 2004)(Small and medium size enterprises' (SME) manufacturing strategy configurations are recognized in a small industrialized economy with the aim to discover how SME manufacturing strategy configurations affect business stability and performance during a period of macroeconomic shock. the second most work done in the published research in the manufacturing area is green manufacturing context. Now a days the Green manufacturing is a challenging manufacturing answer for resolving the world major difficulties which the world facing today, and it is a method for manufacturing to reduce the waste and pollution. It has been also seen finished study that Green manufacturing objective reached through the design and product which covers the entire life cycle of product from conceptual design to disposal causing minimal adverse impact on environment by proper use of resources and reducing the waste and pollution. Green manufacturing has the target to minimize the impact of human actions on the environment (Belkhir et al., 2014). With the green manufacturing another important element for a batter world is recycling the processes. Recently the Malaysian government database on waste management is based on information provided by the concessionaires and Local Authorities. The waste stream surveys were implemented on ad-hoc basis and were not standardized. The recycling data from Local Authorities participating in the National Recycling Program showed uniformity and differ in the accuracy in the data rate. The Ministry of Urban Wellbeing, Housing and Local Government have proactive in the effort to further raise awareness of recycling in Malaysia(Jawahir et al., 2013b). The batter environment, quality manufacturing and controlling waste with standardized recycling is basically improvise towards a sustainable environment. Environmental sustainability is not be achieved without managing the processes efficiently. Past studies have a better work on all the areas in context of sustainability. The past studies also have literature on Natural resources, sustainability dimensions and lean manufacturing. The researcher needs to open the research dimensions towards the other countries in ASEAN, most of the work is done in the Malaysia and Singapore. Researcher have open opportunity to do quality research in remaining parts of ASEAN.

\section{CONCLUSION}

Most of the previous sustainability manufacturing related review articles were based on environmental analysis and evaluation in manufacturing industries. There was a need to review the latest sustainability manufacturing studies in the manufacturing sector in order to show the recent status of sustainability manufacturing from the TBL perspective. Moreover, based on current developments, it was also needed to highlight the major trends and difficulties related to sustainability manufacturing in the ASEAN member countries. This paper reviewed the recent sustainability studies (reported from 2009 to 2018) in manufacturing industries to fill the mentioned 
research gap. An attempt was made to differentiate the sustainable manufacturing studies based on different assessment levels and boundaries. In order to better utilize the findings of this paper, the usefulness and limitations of the studies were also mentioned. This review work showed that most of the reviewed sustainability manufacturing studies were focused don manufactured products, manufacturing plants and processes/work cells. In contrast, manufacturing at the sector and economy levels were not undertaken so frequently. Similarly, most of the reviewed studies were based on a gate-to-gate assessment boundary. Due to data and other resources requirements, only several studies were found with extended boundaries, although studies were reported from ASEAN countries but mostly research is done in Malaysia and focus of the studies was also Malaysian sustainable manufacturing. more efforts are required to get industries from the other part and members of the ASEAN countries on board to improve their sustainability manufacturing performance in a comprehensive way. Analysis of the reviewed studies showed that in order to improve the sustainability manufacturing performance of individual companies, assessments at the manufacturing plant and process/work cell levels should be given more attention in the future while considering all three aspects of sustainability (TBL perspective). The TBL concept is discuss in very limited number of the studies, researcher must work on the advance concepts of TBL and technology to improve the quality of manufacturing. The Malaysian base studies are more in the literature while the other member countries of ASEAN are contribution is very low. The Singapore and Philippines are also contributing a small work but the other members productivity in the literature is very below.

The study has found some new concepts like industry 4.0 revolution in some literature and advance models of manufacturing for sustainability. The researcher must focus on the hybrid processes and IR 4.0 to establishing the sustainable manufacturing procedures in the ASEAN member countries. The study has work on segmentation of industry and SMEs sector which are highly growing economic sector. the new researchers are also having opportunity to explore the concern fields for improvement in the literature. This would help to develop sustainability manufacturing and encourage more manufacturers to assess and improve their sustainability manufacturing performance. More efforts are also required to make the social and economic assessments more effective and practical in manufacturing industries. As more assessment studies were conducted in metal manufacturing industries, it would be wise to consider other manufacturing industries too in order to improve their sustainability manufacturing performance. The paper has quality work on environmental sustainability and past research is having quality work in ASEAN countries greening the environment specially manufacturing procedures and supply chain channels. The waste minimization is discussed in the study and remanufacturing, and recycling procedures are also part of the paper. The study has contribution in lean management for sustainable manufacturing processes and improvement in the delivery of products in time. The automotive industries are also explained with the concept of sustainable manufacturing. The pharmaceutical industries effectiveness and sustainability in the procedures are also part of the study. 
Overall the review paper covers all the possible segments and fields which are available in the past literature. The study is good contribution in the field of sustainable manufacturing in the ASEAN countries.

\section{References}

Adler, P. S. (2012). Managing Flexible Automation. California Management Review, 30(3), 34-56. https: / / doi.org/10.2307/41166513

Allen, D., Bauer, D., Bras, B., Gutowski, T., Murphy, C., Piwonka, T., ... Wolff, E. (2002). Environmentally Benign Manufacturing: Trends in Europe, Japan, and the USA. Journal of Manufacturing Science and Engineering, 124(4), 908. https:// doi.org/10.1115/1.1505855

Aravind, J. (2013). PRODUCTION OF GRAPHENE USING ELECTROMAGNETIC RADIATION (19) United States (12). Google Patents, 1(19). Retrieved from https: / / patents.google.com/patent/US8828193B2/en

Bakshi, B. R., \& Fiksel, J. (2003). The quest for sustainability: Challenges for process systems engineering. AIChE Journal, 49(6), 1350-1358. https: / / doi.org/10.1002/ aic.690490602

Barrera-Roldán, A., \& Saldívar-Valdés, A. (2002). Proposal and application of a Sustainable Development Index. Ecological Indicators, 2(3), 251-256. https://doi.org/10.1016/S1470160X(02)00058-4

Beck, M. E., Bergeron, H., Balla, I., Sangwan, V. K., Lee, H.-S., Chen, K.-S., \& Hersam, M. C. (2018). Multi-terminal memtransistors from polycrystalline monolayer molybdenum disulfide. Nature, 554(7693), 500-504. https: / / doi.org/10.1038/ nature25747

Belkhir, R., Gestermann, N., Koutero, M., Seror, R., Tost, J., Mariette, X., \& Miceli-Richard, C. (2014). Upregulation of Membrane-Bound CD40L on CD4+ T cells in Women with Primary Sjögren's Syndrome. Scandinavian Journal of Immunology, 79(1), 37-42. https: / / doi.org/10.1111/ sji.12121

Blok, V., \& Lemmens, P. (2015). The emerging concept of responsible innovation. Three reasons why it is questionable and calls for a radical transformation of the concept of innovation. In Responsible Innovation 2: Concepts, Approaches, and Applications (pp. 19-36). Cham: Springer International Publishing. https:/ / doi.org/10.1007/978-3-319-17308-5_2

Bogue, R. (2014). Sustainable manufacturing: A critical discipline for the twenty-first century. Assembly Automation, 34(2), 117-122. https:/ / doi.org/10.1108/ AA-01-2014-012

Broman, G. I., \& Robèrt, K. H. (2017). A framework for strategic sustainable development. Journal of Cleaner Production, 140, 17-31. https: / / doi.org/10.1016/j.jclepro.2015.10.121

Brones, F., De Carvalho, M. M., \& De Senzi Zancul, E. (2014). Ecodesign in project management: A missing link for the integration of sustainability in product development? Journal of Cleaner Production, 80, 106-118. https: / / doi.org/10.1016/j.jclepro.2014.05.088

Burke, G. (n.d.). Developing A Framework For Sustainability Management In Engineering SMEs. Robotics and Computer-Integrated Manufacturing. Elsevier. Retrieved from https: / / www.sciencedirect.com/science/article/ pii/S0736584507000166

Crocker, L., \& Algina, J. (1986). Introduction to classical and modern test theory- Test Scores as Composites. Retrieved from https: / / eric.ed.gov/?id=ed312281

Daily, B. F., \& Huang, S. C. (2001). Achieving sustainability through attention to human resource factors in environmental management. International Journal of Operations and Production Management, 21(12), 1539-1552. https: / / doi.org/10.1108/01443570110410892

Diesendorf, Ma. (1999). Sustainability and Sustainable Development by Mark Diesendorf. The Corporate Challenge of the 21st Century, 19-37. Retrieved from http://markdiesendorf.com/wpcontent/uploads/2015/09/CorpSust2000.pdf

Donoghue, M. J., Maddison, D. R., Weston, P. H., Scotland, R. W., Williams, D. M., Swofford, D. L., \& Maddison, W. P. (1999). Two-Dimensional Photonic Band-Gap Defect Mode Laser. Science, 284(June), 1819-1822. Retrieved from http: / / science.sciencemag.org/ content/284/5421/1819.short

Durden, R. F., Cooper, W. J., \& Terrill, T. E. (2007). The American South: A History. The Journal of Southern History, 58(3), 503. https:/ / doi.org/10.2307/2210166 
Glesne, C. (2006). Becoming qualitative researchers, third edirtion. Retrieved from http: / / knowhowtoloseweightfast.com/becoming-qualitative-researchers-anintroduction-read-new-pdfbooks-corrine-glesne.pdf

Held, S. (n.d.). Our Common Future? Pathways to 2050. Books.Google.Com, 1-24. Retrieved from https: / / books.google.com / books?hl=en\&lr=\&id=31RtBQAAQBAJ\&oi=fnd\&pg=PA29\&d $\mathrm{q}=$ Our + common + future $+\mathrm{GH}+$ Brundtland, $+\mathrm{M}+$ Khalid, $+\mathrm{S}+$ Agnelli, $+\mathrm{S}+$ Al-Athel+-

+New+York,+1987\&ots=QRQcAgIJbG\&sig=77KpN-wF36QHQCEapqr8WgJc16I

Herrmann, H., \& Roux, S. (2016). Statistical Models for the Fracture of Disordered Media. Statistical Models for the Fracture of Disordered Media. https: / / doi.org/10.1016/ c2009-0-14278-2

Hillary, R. (2004). Environmental management systems and the smaller enterprise. In Journal of Cleaner Production (Vol. 12, pp. 561-569). https: / / doi.org/10.1016/j.jclepro.2003.08.006

Hsu, C. C., Kannan, V. R., Tan, K. C., \& Leong, G. K. (2008). Information sharing, buyer-supplier relationships, and firm performance: A multi-region analysis. International Journal of Physical Distribution and Logistics Management, 38(4), 296-310. https: / / doi.org/10.1108/09600030810875391

Jawahir, I., Badurdeen, F., \& Rouch, K. (2013a). Innovation in Sustainable Manufacturing Education. Procedia CIRP. Retrieved from http:/ / www.gcsm.eu/Papers/28/0.3_Jawahir.pdf

Jawahir, I., Badurdeen, F., \& Rouch, K. (2013b). Innovation in Sustainable Manufacturing Education. Procedia CIRP, 9-16. Retrieved from http:/ / www.gcsm.eu/Papers/28/0.3_Jawahir.pdf

Jerneck, A., Olsson, L., Ness, B., Anderberg, S., Baier, M., Clark, E., ... Persson, J. (2011). Structuring sustainability science. Sustainability Science, 6(1), 69-82. https://doi.org/10.1007/s11625010-0117-x

Keathley-Herring, H., Van Aken, E., Gonzalez-Aleu, F., Deschamps, F., Letens, G., \& Orlandini, P. C. (2016). Assessing the maturity of a research area: bibliometric review and proposed framework. Scientometrics, 109(2), 927-951. https: / / doi.org/10.1007/s11192-016-2096-x

Lauwers, B., Klocke, F., Klink, A., Tekkaya, A. E., Neugebauer, R., \& McIntosh, D. (2014). Hybrid processes in manufacturing. CIRP Annals - Manufacturing Technology, 63(2), 561-583. https: / / doi.org/10.1016/j.cirp.2014.05.003

Lee, J. (2015). Smart Factory Systems. Informatik-Spektrum, 38(3), 230-235. https: / / doi.org/10.1007/ s00287-015-0891-z

Linke, B. S., Corman, G. J., Dornfeld, D. A., \& Tönissen, S. (2013). Sustainability indicators for discrete manufacturing processes applied to grinding technology. Journal of Manufacturing Systems, 32(4), 556-563. https: / / doi.org/10.1016/j.jmsy.2013.05.005

Mazzarol, T., Volery, T., Doss, N., \& Thein, V. (1999). Factors influencing small business start-ups: A comparison with previous research. International Journal of Entrepreneurial Behaviour \& Research, 5(2), 48-63. https: / / doi.org/10.1108/13552559910274499

Messick, M. D., \& Brewer, B. M. (1983). Solving Social Dilemmas. Review of Personality and Social Psychology, 4, 11-44. Retrieved from https:/ / psycnet.apa.org/ record/2005-11626-030

Miller, J. G., \& Roth, A. V. (2008). A Taxonomy of Manufacturing Strategies. Management Science, 40(3), 285-304. https: / / doi.org/10.1287/ mnsc.40.3.285

Mishra, S. K., Sangwan, N. S., \& Sangwan, R. S. (2007). Phcog Rev .: Plant Review Andrographis paniculata ( Kalmegh ): A Review. Review Literature And Arts Of The Americas, 1(2), 283-298. Retrieved

from https: / / www.researchgate.net/ profile/Siddhartha_Mishra3/publication/281535536_And rographis_paniculata_Kalmegh_A_review/links/59fecbc4a6fdcca1f29c7693/Andrographi s-paniculata-Kalmegh-A-review.pdf

Moldavska, A., \& Welo, T. (2017). The concept of sustainable manufacturing and its definitions: A content-analysis based literature review. Journal of Cleaner Production. https:/ / doi.org/10.1016/j.jclepro.2017.08.006

Mosconi, F. (2015). The new European industrial policy: Global competitiveness and the manufacturing renaissance. The New European Industrial Policy: Global Competitiveness and the Manufacturing Renaissance. https: / / doi.org/10.4324/9781315761756 
Ozanne, J. L., Strauss, A., \& Corbin, J. (1992). Basics of Qualitative Research. Journal of Marketing Research, 29(3), 382. https: / / doi.org/10.2307/3172751

Park, S., Ungson, G., \& Francisco, J. (2016). Asean champions: Emerging stalwarts in regional integration. Retrieved from https://books.google.com/books?hl=en\&lr=\&id=benDQAAQBAJ\&oi=fnd\&pg=PR13\&dq=Park,+Ungson, $+\%$ 26+Francisco, $+2016 \&$ ots $=y e O z$ NILCfE\&sig=nVARwc9zrZ3uemx4oxl2kq7Wa00

Patton, M. Q. (2002). Two Decades of Developments in Qualitative Inquiry: A Personal, Experiential Perspective. Qualitative Social Work, 1(3), 261-283. https: / / doi.org/10.1177/1473325002001003636

Petrini, M., Review, M. P.-B.-B. A., \& 2010, undefined. (n.d.-a). Integrating Sustainability into Business Practices: Learning from Brazilian...: Discovery Service for Southern University and A\&amp;M College. SciELO Brasil. Retrieved from http: / / eds.a.ebscohost.com.subr.idm.oclc.org/eds / pdfviewer/pdfviewer?sid=97ab36630de4-40aa-893c-630fac01e433\%40sessionmgr4006\&vid=1\&hid=4102

Petrini, M., Review, M. P.-B.-B. A., \& 2010, U. (n.d.-b). Integrating Sustainability into Business Practices: Learning from Brazilian...: Discovery Service for Southern University and A\&amp;M College. Retrieved May 23, 2019, from http: / / eds.a.ebscohost.com.subr.idm.oclc.org/eds / pdfviewer/pdfviewer?sid=97ab36630de4-40aa-893c-630fac01e433\%40sessionmgr4006\&vid=1\&hid=4102

Rahimifard, S., Coates, G., Staikos, T., Edwards, C., \& Abu-Bakar, M. (2009). Barriers, drivers and challenges for sustainable product recovery and recycling. International Journal of Sustainable Engineering, 2(2), 80-90. https:/ / doi.org/10.1080/19397030903019766

Rashid, S. H. A., Evans, S., \& Longhurst, P. (2008). A comparison of four sustainable manufacturing strategies. International Journal of Sustainable Engineering, 1(3), 214-229. https: / / doi.org/10.1080/19397030802513836

Roblek, V., Meško, M., \& Krapež, A. (2016). A Complex View of Industry 4.0. SAGE Open, 6(2), 215824401665398. https: / / doi.org/10.1177/2158244016653987

Roxas, B., \& Chadee, D. (2012). Environmental sustainability orientation and financial resources of small manufacturing firms in the Philippines. Social Responsibility Journal, 8(2), 208-226. https: / / doi.org/10.1108/17471111211234842

Rusinko, C. A. (2007). Green manufacturing: An evaluation of environmentally sustainable manufacturing practices and their impact on competitive outcomes. IEEE Transactions on Engineering Management, 54(3), 445-454. https:/ / doi.org/10.1109/TEM.2007.900806

Swamidass, P. M., \& Kotha, S. (1998). Explaining manufacturing technology use, firm size and performance using a multidimensional view of technology. Journal of Operations Management, 17(1), 23-37. https: / / doi.org/10.1016/S0272-6963(98)00016-3

The future of Manufacturing-Making things in a changing world. (n.d.). Deloitte University Press Westlake f... Retrieved from https: / / scholar.google.com / scholar?hl=en\&as_sdt=0\%2C5\&q=Hagel $\% 2 \mathrm{C}+\mathrm{J} .+\mathrm{III} \% 2 \mathrm{C}+\mathrm{Bro}$ wn $\% 2 \mathrm{C}+\mathrm{J} . \mathrm{S} . \% 2 \mathrm{C}+$ Kulasooriya $\% 2 \mathrm{C}+\mathrm{D} . \% 2 \mathrm{C}+\mathrm{Giffi} \% 2 \mathrm{C}+\mathrm{C} .+$ and $+\mathrm{Chen} \% 2 \mathrm{C}+\mathrm{M} .+\% 282015 \%$ $29 \% 2 \mathrm{C}+{ }^{\text {"The }}$ +future+of+manufacturingmaking+things+in+a+changing + world"\% $2 \mathrm{C}+\mathrm{Fut}$ ure+of+the+Business+Landscape $\% 2 \mathrm{C}$

Thomé, A. M. T., Scavarda, L. F., \& Scavarda, A. J. (2016, April 3). Conducting systematic literature review in operations management. Production Planning and Control. https: / / doi.org/10.1080/09537287.2015.1129464

Trace, P. N. (2007). A-priori evaluation of safety functions effectiveness - Methodologies Table of Contents. Evaluation, (027763), 1-38. Retrieved from https: / / scholar.google.com / scholar?hl=en\&as_sdt=0\%2C5\&q=\%28Volkswagen $\% 2 \mathrm{C}+200$ $7 \% 29 \& b \operatorname{tnG}=$

Trianni, A., Cagno, E., Marchesani, F., \& Spallina, G. (2017). Classification of drivers for industrial energy efficiency and their effect on the barriers affecting the investment decision-making process. Energy Efficiency, 10(1), 199-215. https:/ / doi.org/10.1007/s12053-016-9455-6

Upton, N., Teal, E. J., \& Felan, J. T. (2001). Strategic and business planning practices of fast growth family firms. Journal of Small Business Management, 39(1), 60-72. https: / / doi.org/10.1111/0447-2778.00006 
William, F., \& Fazleena, B. (2014). Sustainable Value Stream Mapping (Sus-VSM): methodology to visualize and assess manufacturing sustainability performance. Journal of Cleaner Production, $1(11)$. Retrieved

from https: / / www.sciencedirect.com/science/ article / pii/S0959652614005113

Winter, S. G. (2000). The satisficing principle in capability learning. Strategic Management Journal, 21(1011), $\quad$ 981-996. SMJ125>3.0.CO;2-4 https: / / doi.org/10.1002/1097-0266(200010/11)21:10/11<981::AID-

Yang, X., \& Li, L. (2011). miRDeep-P: A computational tool for analyzing the microRNA transcriptome in plants. Bioinformatics, 27(18), 2614-2615. https: / / doi.org/10.1093/ bioinformatics / btr430

Zhou, H., Keong Leong, G., Jonsson, P., \& Sum, C. C. (2009). A comparative study of advanced manufacturing technology and manufacturing infrastructure investments in Singapore and Sweden. International Journal of Production Economics, 120(1), 42-53. https: / / doi.org/10.1016/j.ijpe.2008.07.013

Zweig, D., \& Webster, J. (2002). Where is the line between benign and invasive? An examination of psychological barriers to the acceptance of awareness monitoring systems. Journal of Organizational Behavior, 23(5), 605-633. https:/ / doi.org/10.1002/job.157 